Jones, $\mathrm{M}^{1}$

Jonathan Edwards Centre Africa University of the Free State

\title{
Calvin and his puritan heirs on Christ's humanity in Hebrews
}

\begin{abstract}
John Calvin was a highly influential second-generation Reformer whose commentaries on most of the books of the Bible shaped the theology and piety of Reformed churches in successive centuries. In his commentary on the Epistle to the Hebrews, Calvin sets forth a Christology that often focuses on how Christ's humanity has practical benefits for the Christian believer. With that in mind, however, his comments on Christ's humanity lack the sophistication found in the writings of several noted Puritan theologians, such as John Owen, Thomas Goodwin, and Stephen Charnock. These Puritan theologians address questions that Calvin was either apparently unwilling to entertain in any detail or unable to give the type of rigorous analysis that we find among his Post-reformation heirs. This article will demonstrate that Calvin's Christology paves the way for more intricate discussions of the person of Christ, and for this reason scholars should acknowledge that later Reformed theologians did not in fact jettison the so-called "Christocentricity" of Calvin, but in fact developed his Christology in ways that were more positive in order to meet the needs of emerging heresies as well as foster a more robust Christian spirituality that focuses on the benefits of Christ's human nature for the Christian believer.
\end{abstract}

\section{INTRODUCTION}

Nobody disputes that John Calvin (1509-1564) played a hugely significant role during the time of the Reformation. As a demonstration of his significance there are literally hundreds of studies devoted to his life and theology. What more can really be said of the Genevan Reformer's life, theology, and influence? Still a great deal, no doubt - a testimony to Calvin's massive output of writing during his years in Geneva. Still, even if every area of Calvin's thought had been analyzed, the fact remains that scholars will still find themselves disagreeing with each other over what Calvin said and why he said this or that, as well as debating his enduring influence (or lack thereof) upon later Christian theologians.

In the secondary literature, a major area of inquiry in Calvin studies over the past several decades has focused on Calvin's relation to the Reformed tradition, particularly his heirs in the Post-Reformation era. ${ }^{2}$ The well-known phrase "Calvin against the Calvinists" refers to the idea promoted by a number of scholars that Calvin's heirs departed from Calvin's theology in various ways, some of which are not insignificant. The "Calvin against the Calvinists" thesis has suffered a number of blows in the last decade or so, but the final death-blow to that

1. Dr Mark Jones, Research Associate, Jonathan Edwards Centre Africa, University of the Free State, P O

Box 339, Bloemfontein, SOUTH AFRICA. E Mail: mark.jones.leiden@gmail.com

2. See Andreas J. Beck \& William den Boer (eds.), "The Reception of John Calvin and His Theology in Reformed Orthodoxy," Church History and Religious Culture 91.1-2 (2011). 11-274. 
NGTT: Oopbron - http://ngtt.journals.ac.za

thesis came with the publication of Richard Muller's most recent work, Calvin and the Reformed Tradition. $^{3}$

This essay attempts to analyze Calvin's understanding of Christ's humanity in the book of Hebrews in comparison to how several Puritan theologians spoke of the humanity of the Godman in their writings on certain passages in Hebrews. The idea that Calvin's heirs somehow lost or jettisoned the "Christocentricity" of Calvin has been adequately refuted in various ways, either by questioning the usefulness of the term "Christocentricity" ${ }^{4}$ or by showing that scholars have sometimes not adequately analyzed the primary sources of those theologians who allegedly departed from Calvin's Christological focus. ${ }^{5}$

This essay contends that while Calvin's 1549 commentary on Hebrews certainly demonstrates an understanding of the benefit of Christ's humanity for his people, his Christology is in fact not as developed as the Christology of later Reformed theologians. There are clear areas of agreement between Calvin and his heirs, but there are also places where they ventured to speak on the benefit of Christ's humanity that Calvin did not address with the same degree of sophistication or, some might argue, speculation.

This can be partly explained by the fact that Calvin was a second-generation codifier of Reformation theology, and for that reason was, as Richard Muller notes, "seldom highly original, and frequently not as detailed or carefully defined in his arguments as would eventually become necessary to resolve the debates of subsequent generations." ${ }^{\prime \prime}$ This point by Muller may surprise many, particularly in the broader Reformed community, who have come to revere Calvin as the greatest theologian of the Reformed church; but the evidence below shows that Calvin's well-known penchant for lucid brevity kept him from making the types of contributions to Christology that one finds among his Puritan heirs in the seventeenth century.

In terms of biblical spirituality, a further aim of this essay is to show that one of the most rewarding studies for anyone wishing to come to a deeper love and appreciation of the Christian faith is to study the man, Christ Jesus, and precisely what it means for him to be not only homoousios with God, but also homoousios with man.

\section{REFORMED CHRISTOLOGIES?}

The Chalcedonian Creed (A.D. 451) provides an orthodox statement of the person of Christ. But anyone familiar with the Christological debates leading to Chalcedon knows full well that

3. Calvin and the Reformed Tradition: On the Work of Christ and the Order of Salvation (Baker Academic: Grand Rapids, 2012).

4. See Richard A. Muller, "A Note on 'Christocentrism' and the Imprudent Use of Such Terminology," Westminster Theological Journal 68 (2006): 253-60.

5. For example, Julie Canlis speaks about the Reformed tradition's decreased emphasis and inadequate understanding of Calvin's doctrine of union with Christ, but she does not really marshal any evidence to support her claim from the primary sources of Reformed orthodox theologians. See "Calvin, Osiander and Participation in God" International Journal of Systematic Theology 6/2 (2004): 177-82. See Muller's response in Calvin and the Reformed Tradition, passim.

6. “The 'Reception of Calvin' in Later Reformed Theology: Concluding Thoughts”, Church History and Religious Culture 91.2 (2011): 256. 
the Creed lends itself to various interpretations. ${ }^{7}$ Scholars continue to debate which side - the Antiochene's or the Alexandrian's? - came out victorious. ${ }^{8}$ In the Western tradition, Roman Catholic, Lutheran, and Reformed theologians have developed Christologies that differ significantly. Of the three aforementioned traditions, only the Reformed tradition is able to do justice to the humanity of Christ. For example, John McGuckin shows that Cyril explained Christ's prayer life "as an economic exercise done largely for our instruction and edification." ${ }^{\prime \prime}$ This is wholly unacceptable for Reformed theologians. Contrary to this position, they believed that Christ, as a true man, needed to pray; which is to say, of course, that he did not pray merely for our instruction. Moreover, in relation to this point, Herman Bavinck correctly notes that Reformed theologians "had fundamentally overcome the Greek-Roman and Lutheran commingling of the divine and the human" in understanding how the two natures related to one another in the one person, Christ Jesus. ${ }^{10}$ Because of the well-known Reformed axiom, finitum non capax infiniti, the human nature of Christ retained its integrity in both his state of humiliation and his state of exaltation.

There were a number of important implications that resulted from this premise. However, even in the Reformed tradition, there has not been entire unanimity on the communicatio idtiomatum. ${ }^{11}$ The difference between how Calvin and John Owen (1616-1683) understand the relationship between the two natures of Christ are rather remarkable. Calvin has been described as the theologian of the Holy Spirit; but it was actually Owen who gave the most erudite and sophisticated account of the relationship between the Holy Spirit and Christ, which enabled him to explain to readers the precise relationship between Christ's two

7. Two relatively recent studies stand out in terms of analyzing the Christology of Cyril of Alexandria (c. 376-444) and Nestorius (386-451): Susan Wessel, Cyril of Alexandria and the Nestorian Controversy: The Making of a Saint and of a Heretic (Oxford: Oxford University Press, 2004); and John McGuckin, Saint Cyril of Alexandria and the Christological Controversy (Crestwood, NY: St. Vladimir's Seminary Press, 2004). McGuckin's analysis, which is deeply sympathetic to Cyril, paints a remarkably fair picture of Nestorius's Christology. Wessel shows that Nestorius was in fact prepared to refer to Mary as theotokos!

8. Among the studies that argue for a Cyrilline victory, see H. Diepen, Les Trois Chapitres au Concile de Chalcédoine (Oosterhout, 1953); John Meyendorff, Christ in Eastern Christian Thought (Washington: Corpus Books, 1969). Conversely, Robert Jenson has argued that Chalcedon leans in an Antiochene direction. See Systematic Theology, 1: The Triune God (New York: Oxford University Press, 1997), ch. 8. Before Jenson, Jaroslav Pelikan also argued for an Antiochene victory: "Even though it may be statistically accurate to say that 'the majority of the quotations come from the letters of St. Cyril,' the contributions of Leo's Tome were the decisive ones." The Emergence of the Catholic Tradition (100-600) (Chicago: University of Chicago Press, 1992), 264.

9. Saint Cyril of Alexandria, 133. Related to this point, Susan Wessel makes the comment that Luke 2:52 "presented Cyril with something of a challenge, for it clearly stated that Jesus advanced in stature, wisdom, and grace....Cyril could say only that Christ's advance and increase were merely apparent." Cyril of Alexandria and the Nestorian Controversy, 133.

10. Reformed Dogmatics: Sin and Salvation in Christ, vol. 3 (Grand Rapids: Baker, 2006), 258.

11. See Stephen Holmes, "Reformed Varieties of the Communicatio Idiomatum" in (eds.) Stephen Holmes \& Murray Rae, The Person of Christ (London: T \& T Clark International, 2005), 70-86.

Calvin describes the communicatio idiomatum thus: "[The Scriptures] sometimes attribute to [Christ] what must be referred solely to his humanity, sometimes what belongs uniquely to his divinity; and sometimes what embraces both natures but fits neither alone. And they so earnestly express the union of the two natures that is in Christ as sometimes to interchange them. This figure of speech is called by the ancient writers 'the communication of properties." Institutes of the Christian Religion (Louisville: Westminster John Knox, 2006), II.xiv.1. 
NGTT: Oopbron - http://ngtt.journals.ac.za

natures. ${ }^{12}$ Not all agree with Owen; but there is very little in Calvin's writings that provide an adequate explanation for why there is such a decided emphasis upon the role of the Holy Spirit in Christ's ministry. For these reasons, and others, the topic of Christ's humanity was an area where a great deal of advancement took place less than a century after Calvin.

\section{LIKE HIS BROTHERS}

Of all the Epistles in the New Testament, the book of Hebrews provides the most fascinating insights into the human nature of Jesus Christ. The first chapter has made readers inescapably aware that Jesus is divine (1:8-12); chapter two makes his humanity equally clear, as verses 14-18 speak of Christ sharing in "flesh and blood", being made "like his brothers in every respect" in order to be a merciful high priest. Commenting on these verses, Calvin states that in Christ's human nature there are two things to be considered, "the essence of the flesh and the affections." ${ }^{13}$ But then he claims that the Son did not need to experience misfortunes "to become accustomed to the emotion of mercy."14 According to Calvin, Christ's life experience and qualification for being a merciful high priest was not, then, for himself, but for us. We are assured of his merciful disposition towards us only because he was acquainted with our miseries. ${ }^{15}$ The emphasis on Christ's learning to be merciful is missing in Calvin.

In the seventeenth century John Owen wrote the most extensive commentary ever on the book of Hebrews. Owen's commentary dwarfs Calvin's in point of length; but more germane to the present discussion, Owen also provides occasion to look at certain points of Christology in a lot more detail than Calvin. Calvin speaks of Christ's mercy and assures believers that Jesus is indeed merciful. But Owen goes farther by distinguishing between God's mercy, which is "but a naked simple apprehension of misery, made effective by an act of his holy will to relieve," and Christ's mercy, which is "a compassion, a condolence, and hath a moving of pity and sorrow joined with it." ${ }^{16}$ This is one example of several where Calvin seems content to give a basic, albeit accurate (in my opinion) answer, whereas Owen draws a great deal more out of the text for his readers.

The issue is not whether Christ is merciful, but whether he is a merciful high priest. God is merciful; but God is not a merciful high priest - it is an ontological impossibility. To be a merciful high priest, the Son had not only to assume a human nature and be called to the priesthood, but he also had to experience miseries, sufferings, and temptations. According to Owen, Christ "had particular experience thereby of the weakness, sorrows, and miseries of human nature under the assaults of temptations; he tried it, felt it, and will never forget it."17 For these reasons, Christ will relieve, favour, and comfort his people by his grace. Christ's experiences did not "add" to his mercifulness, but made him more ready to dispose grace to those who require it. Owen observes that Christ "bears still in his holy mind the sense he had of his sorrows wherewith he was pressed in the time of his temptations, and thereon seeing his

12. See Alan Spence, Incarnation and Inspiration: John Owen and the Coherence of Christology (London:

T\&T Clark International, 2007).

13. John Calvin, The Epistle of Paul the Apostle to the Hebrews and the First and Second Epistles of St.

Peter. Translated by William B. Johnston (Grand Rapids: Eerdmans, 1963), 32.

14. Calvin, The Epistle to the Hebrews, 33.

15. Calvin, The Epistle to the Hebrews, 33.

16. John Owen, An Exposition of the Epistle to the Hebrews. 7 volumes. (Edinburgh: Banner of Truth,

1991), 3:469. Hereafter cited as Commentary on Hebrews, vol:pp.

17. Owen, Commentary on Hebrews, 3:470. 
brethren conflicting with the like difficulties is ready to help them."18 There is much agreement between Calvin and Owen on this matter, but it seems as though there is for Owen a sense in which Christ's human experiences on earth were as beneficial for him as they are for us. Calvin has an almost exclusive emphasis on the latter.

\section{Affections in heaven}

Having previously spoken of Christ's human nature in relation to the priesthood (2:17-18), in chapter four the author of Hebrews brings into distinct focus the role of Christ's humanity in his current high priestly ministry in heaven. Calvin again explains how Christ's life and trials persuade his people that he is merciful towards them. But Calvin also notes that Christ's humanity in heaven has the added benefit of assuring believers that there is no reason to fear him since he is our brother as well as our Lord. His heavenly majesty might cause some to shrink back from seeking him; but his humanity gives us confidence that he is more inclined to take care of us. In this context Calvin raises the "frivolous" question whether the exalted Christ is still subject to our sorrows. ${ }^{19}$ Answering this question would be, to Calvin, nothing more than an "idle speculation." ${ }^{20}$ Nonetheless, in his comments on Matthew 9:36, written in 1555 , he claims that in heaven Christ "does not retain the same feelings to which he chose to be liable in this moral life."21 What Calvin was apparently unwilling to discuss in 1549 he now answers, albeit modestly, several years later.

Among the Reformed orthodox theologians in the seventeenth century, Thomas Goodwin (1600-1680) wrote one of the most sophisticated and penetrating treatises on Christ's humanity in the context of his heavenly ministry. Goodwin ventures to discuss Christ's human affections in his state of glory in the type of detail nowhere found in Calvin's corpus. Indeed, Goodwin raises the question concerning how to distinguish between Christ's affections in his time of weakness and frailty and his remaining affections in his state of glory. He candidly admits this is a difficult question, and judging by his opening discussion one might be persuaded that Calvin's relative simplicity is the best course of action.

Christ's resurrected body is termed a "spiritual" body (1 Cor. 15:44). This does not mean, of course, that he somehow shed his human nature in heaven, but that his body is now "powerful" (Rom. 1:4). Not only Christ's body, but also his affections are "spiritual." According to Goodwin, Christ's affections do not, then, work in his soul only, but also in his body, "as their seat and instrument."22 However, the body is "so framed to the soul that both itself and all the operations of all the powers in it are immediately and entirely at the arbitrary imperium and dominion of the soul."23 In other words, the infirmities in Christ's human nature on earth, experienced in terms of hunger and weakness, do not now affect his soul in heaven because his body is raised in power. Following from this, Goodwin notes that the affections of pity and sympathy move

18.Owen, Commentary on Hebrews, 3:485.

19. Calvin, The Epistle to the Hebrews, 55.

20. Calvin, The Epistle to the Hebrews, 55.

21. John Calvin, Commentary on a Harmony of the Evangelists, Matthew Mark, and Luke. Volume 1.

Translated by William Pringle (Grand Rapids: Baker Books, repr. 2003), 421.

22. The Works of Thomas Goodwin, D.D. 12 vols. (Edinburgh: James Nichol, 1861-66), The Heart of Christ

in Heaven Towards Sinners on Earth, 4:144.

23. Goodwin, The Heart of Christ in Heaven, 4:144. 
NGTT: Oopbron - http://ngtt.journals.ac.za

his "bowels and affect his bodily heart" both in his states of humiliation and exaltation. ${ }^{24}$ But there is this difference: his affections in heaven "do not afflict and perturb him in the least, nor become a burden and a load unto his Spirit, so as to make him sorrowful or heavy." ${ }^{25}$ This is so because Christ's human nature is "impassible" insofar as he cannot experience any hurt now that he is in his glorified state. Jesus is still compassionate and merciful, and thus his perfection does not destroy his affections, "but only corrects and amends the imperfection of them." 26 Echoing the "best of the schoolmen", Goodwin adds, "Passiones perfectivas to be now in him."27

Like Calvin, Goodwin aims to address the benefits of Christ's human nature towards believers. In addressing the abovementioned question, Goodwin states that man has certain affections that are natural, and not the result of sin. In the Garden of Eden, Adam possessed natural affections that were governed not by sin, but by reason. Thus Christ's affections of pity and compassion in his state of glory "quicken and provoke him to our help and succour." ${ }^{28}$ That is to say, Christ is no longer a "man of sorrows", but rather a "man of succours" to his people! There is no doubt that the members of Jesus' bride who remain on earth are living in a world of sin and misery. Christ must necessarily possess affections suitable to their condition while he is in heaven. If heaven was suited only for Christ's personal happiness then there is no need for Christ to possess the affections of sympathy and mercy. But, as Goodwin observes, Christ's relationship to his people is a part of his glory. Therefore, these types of affections are required to be in him if he is to be a good husband to his bride. Moreover, far from being a weakness, Christ's affections of pity and mercy are his strength; it is his glory to be truly and really, even as a man, sensible of all our miseries, yea, it were his imperfection if he were not." ${ }^{29}$

The beauty of Goodwin's theology emerges precisely at this point. Though Christ has shed affections that were once a burden to him, and are thus not compatible or suitable to his state in heaven, there are nonetheless other affections that possess a "greater capaciousness, vastness" that more than makes up for his lack of the former affections. In fact, Goodwin argues that just as Christ's knowledge was "enlarged" in heaven, "so his human affections of love and pity are enlarged in solidity, strength, and reality ... Christ's affections of love are as large as his knowledge or his power." ${ }^{10}$ Another way to look at this would be to argue that since Christ is freed from oppressive affections it actually gives greater scope to his effective affections - being free from grief actually lets you be more compassionate. So, for example, when you yourself are desperately hungry other people's problems don't receive your best attention. This can be applied to Christ based on the theology that Goodwin sets forth.

Whereas Goodwin uses Hebrews 4:15 to discuss what affections are now in Christ in his heavenly state, Calvin actually claims that the author "does not discuss the nature of Christ in Himself, but His nature as He shows Himself to us."31 So while both Calvin and Goodwin are concerned to highlight the pastoral value of Christ's humanity in heaven, Goodwin ventures

24. Goodwin, The Heart of Christ in Heaven, 4:145.

25. Goodwin, The Heart of Christ in Heaven, 4:145.

26. Goodwin, The Heart of Christ in Heaven, 4:145.

27. Goodwin, The Heart of Christ in Heaven, 4:145.

28. Goodwin, The Heart of Christ in Heaven, 4:145. To "succour" is to give help, especially in times of difficulty.

29. Goodwin, The Heart of Christ in Heaven, 4:146.

30. Goodwin, The Heart of Christ in Heaven, 4:146.

31. Calvin, The Epistle to the Hebrews, 55. 
into territory that Calvin does not. Some might argue that Calvin is less "speculative" than his heirs on certain questions; others might contend, however, that Calvin simply is not as sophisticated as later Reformed theologians - after all, he was not a trained theologian in the same manner as Reformed theologians in the period of high orthodoxy. Goodwin's example might show that his Christological concerns enabled him to draw more out of Hebrews 4:15 than Calvin. As a result, the question between Calvin and a later "Calvinist" is not one so much of divergence, but rather one of heightened clarity and greater spiritual value.

Another example of the value of good Christology in relation to a believer's personal frailties comes from Stephen Charnock (1628-1680). Looking at Hebrews 4:15, Charnock argues that because of the incarnation "an experimental compassion" was gained which the divine nature was not capable of because of divine impassibility. ${ }^{32}$ As our sympathetic high priest, Christ "reflects" back on his experiences in the world and so the "greatest pity must reside in him" because the "greatest misery was endured by him." Christ is unable to forget above what he experienced below. ${ }^{33}$ Charnock does not intend to say that Christ's human nature suffers in any way, which would contradict Goodwin. Instead, he is speaking about Christ's knowledge and memory of his sufferings as the means by which Christ is able to be sympathetic to his people in a way that would otherwise be impossible if the Son did not assume a human nature. Consequently, the value of an elaborate Reformed Christology for the advancement of biblical spirituality cannot be overstated.

\section{LEARNING OBEDIENCE}

The idea that the God-man, Jesus Christ, learned obedience (Heb. 5:8) has been a perplexing thought to some, both laypeople and many pastors as well. Calvin constantly aims to draw out the benefits of Christ's humanity to his people. It is a constant refrain in his exegesis of Hebrews. Calvin's focus may even cause him to miss the point of Hebrews 5:8. He notes that Christ was "more than willing" to obey the Father; but he obeyed "for our own benefit, to give us the instance and pattern of His own submission even to death itself." ${ }^{34}$ Moving to a more decidedly Christological focus, Calvin does affirm that Christ, by suffering, including his death, learned what it was to obey God. However, his analysis of what it means for Christ to "learn obedience" is rather anemic in his comments on Hebrews 5:8.

In discussing the obedience spoken of in Hebrews 5:8, Owen distinguishes between Christ's general obedience, which refers to the whole pattern of his life on earth, and Christ's peculiar obedience, which refers specifically to his obedience unto death. ${ }^{35}$ This verse in question has in view particularly the latter understanding of obedience. Following from that, to learn obedience has a threefold sense: 1. To learn it materially, that is, to be taught by God to obey him, which we were at some time ignorant of. This does not apply to Christ, for he knew what was required of him. 2. To learn it formally, which has in view God's instruction, help, and direction of us in our acts of obedience because we are weak and unskilful. Again, this could not be true of Christ since he always had a fullness of grace, and so constantly knew what he had to do and was perfectly willing to do what was required of him. 3. To learn obedience

32. Stephen Charnock, A Discourse of Christ's Intercession in The Complete Works of Stephen Charnock. 5 vols. (Edinburgh: James Nichol, 1864), 5:106.

33. Charnock, A Discourse of Christ's Intercession, 5:106.

34. Calvin, The Epistle to the Hebrews, 65-66.

35. Owen, Commentary on Hebrews, 4:523. 
NGTT: Oopbron - http://ngtt.journals.ac.za

through experience. By undergoing such severe trials of hardship, even death on a cross, Christ learned suffering-obedience. This type of obedience required suffering so that his knowledge of suffering might be of great value to the church. ${ }^{36}$ All of Christ's life was one of suffering. In his sufferings he "had occasion to exercise those graces of humility, self-denial, meekness, patience, faith, which were habitually present in his holy nature, but were not capable of the peculiar exercise intended but by reason of his sufferings." ${ }^{37}$ Owen makes a pastoral note that should not go unnoticed. He claims that in God's dealing with men, those who have been most afflicted have also been the "most humble, most holy, fruitful, and wise among them" - no doubt this applies to Christ himself. ${ }^{38}$ By the use of various distinctions, Owen gives his readers a lot more to think about concerning Christ's obedience than Calvin. Calvin aims to help his readers with his remarks on Christ's humanity, but Owen helps his readers more because his exegesis is more elaborate and detailed than Calvin's.

\section{A BODY PREPARED}

Hebrews 10:5 draws on Psalm 40:6 to address the body that was prepared for Christ by the Father. Instead of explaining what this verse means relative to the incarnation and Christ's human nature, Calvin spends his time explaining why "the Apostle" used Psalm 40:6 the way he did. After all, Calvin rightly notes that Psalm 40:6 reads "you have given me an open ear." The Septuagint translation (Ps. 39:7-9) understands this phrase to indicate the creation of a person's body, which the author of Hebrews picks up on rather than quoting the Masoretic text. Calvin comments that the Apostles were "not over-scrupulous in quoting words provided that they did not misuse Scripture for their convenience."39

Calvin's "lucid brevity" on this verse is inexcusable, for his readers are not given any hint of what it means for Christ that a body was prepared for him. This verse addresses directly the humanity of Christ, and an important detail of who "prepared" the body the Son was to assume.

In his learned commentary on Hebrews, the Puritan theologian William Gouge (1575-1653) notes that "body" is meant by way of synecdoche to refer to the soul as well. ${ }^{40}$ In the context of Hebrews 10, the human nature of Christ is necessary for Christ to be able to offer a sacrifice. Gouge understands the word "prepared" in 10:5 as a compound which signifies "to make perfect." ${ }^{41}$ The Father "ordained, formed, made fit and able Christ's human nature to undergo, and fulfil that for which he was sent into the world." ${ }^{42}$ Following from this, Gouge contends that God enables men in specific ways to do the work for which they have been set apart. In other words, God does not "send forth dumb Orators...lame messengers. Such are not prepared of God." 43

God prepared a sinless body, and fitted Christ with the requisite gifts and graces to perform the work of mediator. Owen picks up on this very theme, and notes that the body prepared

36. Owen, Commentary on Hebrews, 4:524.

37. Owen, Commentary on Hebrews, 4:525.

38. Owen, Commentary on Hebrews, 4:530.

39. Calvin, The Epistle to the Hebrews, 136.

40. William Gouge, A learned and very useful commentary on the whole epistle to the Hebrews (London,

1655), 436.

41. Gouge, Epistle to the Hebrews, 436.

42. Gouge, Epistle to the Hebrews, 436.

43. Gouge, Epistle to the Hebrews, 437. 
for Christ by the Father was "the effect of the mutual counsel of the Father and the Son." ${ }^{44}$ According to the terms of the covenant of redemption the Father was required to provide the Son with all things needed to be able to fulfil the will of the Father. According to Owen, "Among those the principal was, that the Son should have a body prepared for him, that so he might have somewhat of his own to offer." 45 Two of Owen's "observations" are worth noting. They are beautiful instructions to believers on how they ought to respond to the idea that the Father prepared a body for the Son. First, that we should praise the Father for the "holy properties" of Christ's human nature. ${ }^{46}$ Second, in connection with the first point, it was the Father who not only "prepared" the Son's body, but also "filled it with grace...strengthened, acted, and supported it in [Christ's] whole course of obedience." ${ }^{\prime 47}$

After that, Owen claims that a more particular inquiry is required into the nature of this preparation of a body by the Father for Christ. He highlights ten points for consideration: 1. That the body should come from the loins of Abraham; 2 . That the body should be free from sin; 3. That the body should consist of real flesh and blood; 4 . That the body should have a rational soul; 5 . That the body should be able to undergo sorrows and sufferings; 6 . That this body could be tempted by outward temptations; 7 . That the body could physically die; 8 . That the same body could be raised again from the dead; 9 . That his soul could be with God in heaven while his body lay in the grave; and 10. That his body was visibly taken to heaven, and there resides. ${ }^{48}$

Gouge's explanation is no doubt sufficient, and he pulls something out of the text that not only explains what the verse means, but also some practical application for his readers. Owen, true to form, takes verse 5 and draws out many important truths about Christ's humanity along with several applications that should cause believers to marvel at the wonder of the Father's preparation of Christ's body. Calvin does not commit any sins of commission, so to speak, but his apparent reluctance to be too prolix in his commentaries essentially robs his readers of insights into Christ's humanity.

\section{Conclusion}

What conclusions can be drawn from this brief analysis of how Calvin and the "Calvinists" understood the humanity of Christ in the book of Hebrews? First, there is little doubt that Calvin's Christology is not nearly as developed as what we find in many later Reformed theologians. His Institutes, which were not analyzed in this essay, were a manual for ministers. Despite the fact that the Institutes are one of Christ's greatest gifts to the church, the theology contained in that work is not nearly as intricate and refined as the writings of later Reformed Protestant scholastics, such as Petrus van Mastricht (1630-1706) and Francis Turretin (16231687). This is not to minimize Calvin's obvious genius and importance; but it seems to me that there is a sort of existential crisis among many Reformed churchmen, and indeed even some scholars, who feel the need to make too much out of Calvin - as if getting the Reformer to agree with our position is the ace in the pack. Perhaps if the Latin writings of other theologians had been translated, as Calvin's have, the typical view of Calvin would be slightly modified.

44. Owen, Commentary on Hebrews, 6:460.

45. Owen, Commentary on Hebrews, 6:461.

46. Owen, Commentary on Hebrews, 6:461.

47. Owen, Commentary on Hebrews, 6:461.

48. Owen, Commentary on Hebrews, 6:462-64. 
NGTT: Oopbron - http://ngtt.journals.ac.za

Second, as this essay has shown, Calvin's commentary on Hebrews was less than detailed, sometimes even neglecting to actually comment on the passage in question. The specific details that would need to be answered by Calvin's heirs did not appear to occur to Calvin to answer at the time, though it is interesting that Peter Martyr Vermigli (1500-1562) did in fact answer certain questions with a great deal more clarity than Calvin.

Third, Calvin's omissions and absences of detail may reflect an "anti-speculative" bent on his part, which some find appealing. But the precision and clarity of later theologians such as Owen, Goodwin, and Charnock on the humanity of Christ actually fosters a richer, deeper spirituality. Knowledge of the person and work of Christ is the chief part of Christian growth. Calvin paved the way - he pioneered the threefold office of Christ - and his heirs have done much to improve on his own contributions. This is precisely how theology ought to function in the Reformed church. And I have little doubt that a Calvinistic Baptist such as Professor Haykin would heartily agree with that sentiment.

\section{BiBLIOGRAPHY}

Bavinck, H 2006. Reformed Dogmatics: Sin and Salvation in Christ, vol. 3 (Grand Rapids: Baker).

Beck, A J \& Den Boer, W (eds) 2011. "The Reception of John Calvin and His Theology in Reformed Orthodoxy." Church History and Religious Culture 91.1-2, 11-274.

Calvin, J 1963. The Epistle of Paul the Apostle to the Hebrews and the First and Second Epistles of St. Peter.

Translated by William B. Johnston (Grand Rapids: Eerdmans).

Calvin, J 2003. Commentary on a Harmony of the Evangelists, Matthew Mark, and Luke. Volume 1.

Translated by William Pringle (Grand Rapids: Baker Books).

Calvin, J 2006. Institutes of the Christian Religion (Louisville: Westminster John Knox).

Charnock, S. A Discourse of Christ's Intercession. In The Complete Works of Stephen Charnock. 5 vols.

(Edinburgh: James Nichol, 1864).

Canlis, J 2004. "Calvin, Osiander and Participation in God." International Journal of Systematic Theology 6/2, $177-82$.

Diepen, H 1969. Les Trois Chapitres au Concile de Chalcédoine (Oosterhout, 1953).

Goodwin, T. The Heart of Christ in Heaven Towards Sinners on Earth. In The Works of Thomas Goodwin,

D.D. 12 vols. (Edinburgh: James Nichol, 1861-66).

Gouge, W 1655. A learned and very useful commentary on the whole epistle to the Hebrews (London).

Holmes, S 2005. "Reformed Varieties of the Communicatio Idiomatum." In Stephen Holmes \& Murray Rae

(eds) 2005. The Person of Christ (London: T \& T Clark International), 70-86.

Holmes S \& Rae M (eds) 2005. The Person of Christ (London: T \& T Clark International).

Jenson, R 1997. Systematic Theology, 1: The Triune God (New York: Oxford University).

McGuckin, J 2004. Saint Cyril of Alexandria and the Christological Controversy (Crestwood, NY: St. Vladimir's

Seminary Press).

Meyendorff, J 1969. Christ in Eastern Christian Thought (Washington: Corpus Books).

Muller, R A 2006. "A Note on 'Christocentrism' and the Imprudent Use of Such Terminology." Westminster Theological Journal 68, 253-60.

Muller, R A 2011. "The 'Reception of Calvin' in Later Reformed Theology: Concluding Thoughts", Church History and Religious Culture 91.2, 255-274.

Muller, R A 2012. Calvin and the Reformed Tradition: On the Work of Christ and the Order of Salvation (Baker Academic: Grand Rapids).

Owen, J 1991 An Exposition of the Epistle to the Hebrews. 7 volumes. (Edinburgh: Banner of Truth).

Pelikan, J 1992. The Emergence of the Catholic Tradition (100-600) (Chicago: University of Chicago Press).

Spence, A 2007. Incarnation and Inspiration: John Owen and the Coherence of Christology (London: T\&T

Clark International).

Wessel, S 2004. Cyril of Alexandria and the Nestorian Controversy: The Making of a Saint and of a Heretic

(Oxford: Oxford University Press). 
NGTT Deel 54, Nommers 1 \& 2, Maart en Junie 2013

John Calvin

John Owen

Puritans

Humanity of Christ

Post-reformation theology

Hebrews 